\title{
Parental drinking according to parental composition and adolescent binge drinking: findings from a nationwide high school survey in Japan
}

\author{
Satoshi Inoura ${ }^{1 *} \mathbb{D}$, Takuya Shimane ${ }^{1}$, Kunihiko Kitagaki $^{2}$, Kiyoshi Wada ${ }^{3}$ and Toshihiko Matsumoto ${ }^{1}$
}

\begin{abstract}
Background: Alcohol problems in parents have been revealed to affect adolescent alcohol misuse. However, few studies examine the effects of parental drinking on adolescent risky drinking (including binge drinking) in the general population. In particular, previous study findings are inconsistent regarding the influence of parental drinking according to parental composition. In this study, we aimed to examine the relationship between parental drinking, according to parental composition, and binge drinking among high school students in Japan.

Methods: We performed a secondary analysis of the Nationwide High School Survey on Drug Use and Lifestyle 2018, Japan. A total of 46,848 valid surveys from high school students of 78 schools were included for analysis. Logistic regression analysis with a generalized linear mixed model was conducted with binge drinking as the dependent variable and "parental drinking according to parental composition" (e.g., father's drinking, mother's drinking, father's absence, mother's absence, both parents drinking, and neither parent at home) as the independent variable, after adjusting with covariates. Binge drinking was defined as five or more alcoholic drinks for male adolescents or four or more alcoholic drinks for females on the same occasion within two hours.

Results: In the fully adjusted models, adolescents whose mothers drink (adjusted odds ratio (AOR): 1.50, 95\% confidence interval (Cl): 1.06-2.12) were significantly associated with adolescent binge drinking. This risk was significantly higher among students with neither parent living at home (AOR: 4.35, 95\% Cl: 2.10-9.02).

Conclusion: Parental drinking and absence do affect adolescent binge drinking; our findings show that adolescents are more likely to engage in binge drinking if their mothers drink or if they are not living with either parent. Therefore, it is important to engage parents and non-parental family members in future programs and interventions to prevent adolescent binge drinking.
\end{abstract}

Keywords: Parental drinking, Parental composition, Binge drinking, Adolescent, High school, School survey

\footnotetext{
* Correspondence: inourasa2002@yahoo.co.jp

'Department of Drug Dependence Research, National Institute of Mental

Health, National Center of Neurology and Psychiatry, Tokyo, Japan

Full list of author information is available at the end of the article
}

(c) The Author(s). 2020 Open Access This article is licensed under a Creative Commons Attribution 4.0 International License, which permits use, sharing, adaptation, distribution and reproduction in any medium or format, as long as you give appropriate credit to the original author(s) and the source, provide a link to the Creative Commons licence, and indicate if changes were made. The images or other third party material in this article are included in the article's Creative Commons licence, unless indicated otherwise in a credit line to the material. If material is not included in the article's Creative Commons licence and your intended use is not permitted by statutory regulation or exceeds the permitted use, you will need to obtain permission directly from the copyright holder. To view a copy of this licence, visit http://creativecommons.org/licenses/by/4.0/ The Creative Commons Public Domain Dedication waiver (http://creativecommons.org/publicdomain/zero/1.0/) applies to the data made available in this article, unless otherwise stated in a credit line to the data. 


\section{Background}

Alcohol misuse is common among adolescents. A recent survey found that approximately $2.4 \%$ of high school students in Japan [1] engage in binge drinking, which is lower than the data from other countries, including the United States (14.4\% of 12th graders [2]) and Europe (35.0\% of adolescents aged 16 years [3]). Although the prevalence of binge drinking in Japan is low when compared internationally, we should not make light of this problem because youth binge drinking increases the risk of alcohol-related disorders (including intoxication), accidents, fatal injuries, and chronic illness [4]. Binge drinking also increases the risk of both acute and longterm negative consequences (e.g., injuries and alcohol disorders) [5], essentially, effecting further risk behaviors such as illegal substance use and sexual and violent behaviors [6-8]. Japanese culture includes a deep-rooted phenomenon similar to alcohol chugging. Often observed in society and media advertisements [9], it relates to risky heavy drinking, promoting positive perceptions and attitudes about alcohol consumption, and potentially affecting children's beliefs and behaviors toward alcohol consumption. In fact, heavy underage and college drinking have been reported recently [10,11], making it essential to raise awareness of the dangers of binge drinking and understanding and addressing the environmental factors surrounding adolescents, including the person themselves, at an early stage.

Emerging health research suggests that alcohol use is determined by multidimensional (including biological, psychological, and sociocultural) factors [12]. Genetic variants affect the risk of alcohol misuse. Candidate genes related to alcohol dependence can be categorized into three groups: those related to (a) alcohol metabolism, (b) the stress response system, and (c) behavioral disinhibition [13, 14]. With respect to alcohol metabolism, alcohol dehydrogenase and aldehyde dehydrogenase are known to have a protective influence against excessive drinking and alcohol dependence [15]. Regarding the stress response system, the initiation and retention of binge drinking behavior and alcohol dependence are related through dysregulated activation of the brain stress system by corticotropin-releasing hormones [16, 17]. Behavioral disinhibition, defined as the inability to inhibit socially restricted actions, including alcohol and other substance abuse, is related to the serotonin and dopamine pathways $[18,19]$. Previous studies have associated polymorphisms of tryptophan hydroxylase, serotonin transporter and serotonin receptor genes in the serotonergic system, polymorphisms on dopamine receptors, dopamine $\beta$-hydroxylase, and tyrosine hydroxylase with risks of binge drinking and alcohol dependence [14, 20-22].
Psychological traits related to cognitive and emotional susceptibility to substance abuse are also crucial factors for the initiation and development of adolescent substance abuse [23]. Among these, impulsivity and sensation seeking have received the most attention owing to their influence on risky behaviors (including drinking alcohol) $[24,25]$ with high levels being especially influential [26]. Adolescents, in particular, may be more sensitive to alcohol's reward and stimulant effects [27], but less so to its sedative effects [28]. Several studies imply that neural changes during adolescence may temporarily increase sensitivity to certain effects (e.g., reward) of alcohol, promoting consumption during a drinking episode. It may also decrease sensitivity to other effects (e.g., sedative effects) that may help to limit drinking during an episode [29].

Regarding sociocultural factors, etiological mechanisms representing multiple systems (including family, peers, and community) interact across development to influence binge drinking tendencies [30]. Here, family plays an essential role. Not only does parental drinking have a crucial influence on children, but studies [31,32] show that disrupted family relationships (including parental separation or divorce) and parental intactness are associated with binge drinking. Furthermore, parental control and support are essential in preventing adolescents from engaging in risky drinking behaviors [33], since low warmth and low parental monitoring regarding their child's alcohol use are associated with higher adolescent binge drinking prevalence [34]. Importantly, binge drinking occurs where there is no parental supervision, such as someone else's home [35]. During high school, an adolescent's social context shifts from family to peers. Binge drinking may be facilitated by the presence of peers and peer selection [36,37]. Community factors include the neighborhood and school environment. A supportive school environment (e.g., incorporating alcohol prevention into the curriculum) is associated with reduced adolescent binge drinking independent of individual, family, and peer risk factors [38].

Recent studies have focused on the influence of alcohol use on others, including the potential impact of parental drinking on children, especially adolescent alcohol misuse. Whereas most studies focused on alcoholics and parents who had problems with alcohol [39], some recent ones included normative drinking patterns to analyze their influence on alcohol misuse among children in general. Results revealed that parental drinking habits affect early-onset drinking in children [40] and increase the risk of adolescent alcohol misuse and intoxication [41, 42]. Domestically, higher scores on the Children of Alcoholics Screening Test in high school and college students [43] reflect frequent drinking among parents. 
Parental alcohol use increases the intensity of alcohol consumption in late adolescent life [44, 45]. Whereas heavy (and moderate frequency) drinking predicts larger amounts of alcohol consumption throughout adolescence [46], the frequency promotes the development of a risky trajectory in adolescent alcohol use [47]. One study reports the predictive effects of paternal drinking frequency and volume on binge drinking among younger adolescents [48]. Some studies identify research gaps in examining associations between parental drinking and child drinking $[39,42]$. Research has mostly focused on addressing the association between parental drinking and habitual (chronic risk) adolescent drinking, but little is known about its association with adolescent binge drinking (an acute risk).

Similarly, the effects of parental drinking according to gender differences remain unclear. The study that revealed that paternal drinking frequency and intensity predicted excessive adolescent drinking for younger adolescents, also conceded that higher overall alcohol consumption rates may have influenced the results reflecting the father's dominant influence [48]. In contrast, many studies have reported the dominant effects of maternal drinking on adolescent alcohol misuse (although fewer reports exist on child binge drinking resulting from the mother's drinking). For instance, only maternal drinking in two-parent families was significantly associated with adolescent drinking [49], with adolescents drinking more often when maternal drinking exceeded paternal drinking $[47,50]$.

Women are more susceptible to alcohol-related problems than men, their blood alcohol concentration tends to increase rapidly, and apart from potentially causing fetal alcohol syndrome (from drinking during pregnancy) [51], their problematic drinking behaviors may negatively influence their parenting. That is because mothers (typically) provide much of the child care [52] and better overall supervision, establishing stronger affective and interpersonal bonds with their children [53] compared to fathers, thus, those with drinking habits may exhibit an approving attitude toward their child's alcohol use [54] and their alcohol consumption recommendations (to the child) may be a risk factor [55]. Therefore, we predict that maternal drinking may influence binge drinking among adolescents.

Another concern related to parental drinking, is how both parents' drinking influences the risk of binge drinking among adolescents. Previous studies have found that both the mother's and father's drinking increased the risk of adolescent drinking [56], and both parents using alcohol, significantly predicted adolescent alcohol misuse $[57,58]$. In particular, heavy drinking by both parents predicted an earlier onset and a marked increase in adolescent drinking [46]. However, the influence of both parents' drinking habits on adolescent binge drinking is unrevealed, but considering existing evidence, the social learning theory may be applicable [59]. Adolescents model their parents' behavior [60], conceptualizing the process of parental drinking, which encourages adolescent drinking [47]. A Japanese study showed that drinking in front of children had a greater influence than parents' daily alcohol consumption. Nearly $80 \%$ of fathers and over $50 \%$ of the mothers in the surveyed sample drank in front of their children [55]. The phenomenon of both parents in a family drinking may be associated with a more favorable attitude toward alcohol use (a longitudinal predictor of alcohol initiation and misuse later) [41], increased availability of alcoholic beverages, and the likelihood of drinking. In fact, most Japanese high school students who drink, find alcoholic beverages at home [61]. Furthermore, parental permissiveness promotes higher binge drinking prevalence [62]. Similarly, research implies that children of parents whose drinking places them in the middle consumption tier, are more exposed to negative outcomes. These include less attention and time to complete homework and irregular bedtime owing to their parent's drinking [63]. We predict that households where both parents drink heavily, may be more influential in adolescent binge drinking than where only one parent drinks.

Another challenge is whether parental composition (for example, father's absence and mother's absence) will affect child binge drinking. Most studies that examine the relationship between parental factors and adolescent drinking fail to separate the father's and mother's influence [39], report across parents, or lack information about the father's drinking [56]. Literature shows that adolescents from two-parent households are less prone to excessive alcohol use (including binging) than those from single-parent households [64], who are more likely to drink [40]. Studies show that adolescents from nonintact families tend to drink more [33], disrupted families are related to child binge drinking [31], and adolescents engage in more frequent heavy drinking (including binging) when they do not live with both their biological parents [32].

Regarding the effects of gender differences (in singleparent households) on children's drinking behaviors, alcohol use and delinquent behaviors among adolescents were higher in single-father homes than in singlemother homes, owing to lower levels of parental supervision observed in single-father homes [65]. Research shows that children from single (mothers or fathers) parent homes were at higher risk of various behavioral problems (including alcohol use) than children from two-parent families. However, following control for confounders, only the single-father group's results remained significant [66]. Despite the latter and research showing 
that living with a single mother was associated with less heavy drinking than a single father [32], one study showed that poor mother-child communication in single-parent families increased hazardous drinking and drunkenness in adolescents [67]. In this regard, it appears that parents' control and support functions may differ according to gender. A Chinese survey showed: children in non-intact families reported their fathers exerted more paternal behavioral control (knowledge about their child, expectations, supervision, discipline, and demandingness) and their mothers more maternal psychological control (engaging their children's feelings and thoughts) [68]. Moderate amounts of family support and control would be effective for the socialization and development of sensible drinking in an individual [33], but parents lack in their parenting (including support and control) when drinking excessively [45], potentially causing deviant or excessive drinking behavior in adolescents.

Thus, adolescents from non-intact families are ostensibly associated with binge drinking. Also, since men and women have important but different roles affecting a child's development, both living without a mother or a father, may hold binge drinking risks for adolescents. Next, we predict that for adolescents not living with either parent influences the prevalence of binge drinking. Related to this, past studies found that children living without both their biological parents engage more frequently in heavy drinking [32, 33, 69]. Importantly, many adolescents do not live with either parent owing to divorce or the death of a parent [70] which may affect their socialization process, since parents are the primary socialization agents during childhood and early adolescence and parents' values and norms represent the first model for children. Furthermore, limited control and support in deficient families may cause deviant behavior in children [33]. In particular, fragmented families increase the risk of frequent drinking and drunkenness among adolescents [31, 67], while adolescents without parents may have less protective (including parental control) support [48], monitoring, and parental warmth, which could have lowered the risk of binge drinking [34]. Thus, we predict that adolescents who live with neither parent have experienced poor family functions, potentially causing delinquency and risky child behavior, including binge drinking.

Considering the above, we aimed to investigate the relationship between current parental drinking, according to parental composition, and binge drinking among high school students in Japan. Our hypothesis is that parental drinking (mother drinking and both parents drinking) and parental composition (father's absence, mother's absence, and neither parent present) would affect adolescent binge drinking. Particularly, we test whether the effects of father drinking and mother drinking separately, as well as the effects of father's absence and mother's absence separately, are associated with adolescent binge drinking behavior. Next, we test whether the combined effects of the (a) father and mother drinking and/or (b) father's and mother's absence, further influence adolescent binge drinking.

\section{Methods}

\section{Aim and design}

The aim of the Nationwide High School Student Survey on Drug Use and Lifestyle 2018 was to examine the current situation of drug use, including alcohol and tobacco, among Japanese high school students, whose findings informed a drug abuse prevention strategy in Japan. The survey was a cross-sectional study conducted between October 2018 and March 2019.

This study used secondary data from the Nationwide High School Student Survey on Drug Use and Lifestyle 2018 which was conducted by the National Institute of Mental Health in Japan.

\section{Participants, process, and setting}

Participants were high school students randomly selected using a stratified single-stage cluster method, with six regions as the strata and schools as the cluster. Schools were selected using random sampling with probability proportionate to the number of high school students in each region. Self-administered questionnaires were distributed to students in each classroom; these were selected by the person in charge of substance abuse prevention at each school. The teacher in each classroom collected the completed questionnaires and returned them to our research center. A total of 116,313 students at 140 high schools nationwide were surveyed.

\section{Materials}

A self-developed questionnaire (43 items) was used in the original survey. The analysis included demographic and lifestyle variables, information on students' binge drinking experiences, and their parents' drinking status and absence, as below.

\section{Dependent variable: adolescents' binge drinking during the previous month}

We defined binge drinking as five or more alcoholic drinks for male participants or four or more alcoholic drinks for female participants on the same occasion within two hours [71]. Students were asked, "In the past month, how many days were you at a drinking function (e.g., a gathering that lasted two hours or more) where you had many drinks (five or more drinks for males, four or more drinks for females)?" The response options were: not even once (1), 1 to 2 days (2), 3 to 5 days (3), 6 
to 9 days (4), 10 to 19 days (5), 20 to 29 days (6), and every day (7). These responses were recoded as "past month binge drinking," with response options: no (0) or yes (1).

\section{Independent variable: parental drinking according to parental composition}

Students were asked the status of their parents' alcohol use. First, they were asked: "Does your father consume alcohol regularly?" with response options No (1), Sometimes (2), Every day (3), and No father at home (including working away from home, deceased, separated, or divorced) (4). Second, the following question was asked: "Does your mother consume alcohol regularly?" with response options No (1), Sometimes (2), Every day (3), and No mother at home (including working away from home, deceased, separated, or divorced) (4). For both questions, single answers were allowed. If respondents answered, "No father at home" or "No mother at home," they were not allowed to answer the question related to their parents' drinking status.

Then, the responses were recoded as a) "Father's alcohol use status and absence" with response options: $\mathrm{FN}=$ Father does not drink (1), FD = Father drinks (2), or $\mathrm{NF}=$ No father at home (3), and b) "Mother's alcohol use status and absence" with options: $\mathrm{MN}=$ Mother does not drink (1), $\mathrm{MD}=$ Mother drinks (2), or $\mathrm{NM}=\mathrm{No}$ mother at home (3). We finally combined and reencoded the two items as "Parental drinking according to parental composition" with response options: FN/ $\mathrm{MN}=$ Neither father nor mother drinks (1), FN/MD = Father does not drink but mother drinks (2), FN/NM = Father does not drink and no mother at home (3), FD/ $\mathrm{MN}=$ Father drinks but mother does not drink (4), FD/ $\mathrm{MD}=$ Both father and mother drink (5), $\mathrm{FD} / \mathrm{NM}=$ Father drinks and no mother at home (6), NF/MN = No father at home and mother does not drink (7), NF/MD = No father at home and mother drinks (8), and NF/NM = Neither father nor mother at home (9).

The family options were: "both father and mother (two-parent) family" (FN/MN [1], FN/MD [2], FD/MN [4], or FD/MD [5]), father-only family (FN/NM [3] or FD/NM [6]), mother-only family (NF/MN [7] or NF/MD $[8]$ ), and neither-parent family (NF/NM [9]).

\section{Covariates}

Models 2 and 3 included demographic variables that had been associated with adolescent binge drinking in prior research. Covariates included sex, grade [8], lifestyle habits (including getting up and going to the bed at the same time daily, breakfast eating) [63], school life (including enjoying school) [72], family factors (including eating dinner with one's family, hours spent in the absence of adults, talking with one's parent about problems) [55, 73, 74], peer factors (including having close friends to hang out with or consult, drinking with peers) [36, 37], thoughts on underage drinking [75], and confidence in refusing a substance when offered [31].

\section{Statistical analysis}

We performed descriptive analysis (using frequency and percentage values) to characterize the sample (Table 1) and assess the distribution of fathers' drinking and absence status (FN, FD, NF) and mothers' drinking and absence status (MN, MD, NM) by adolescent binge drinking (Table 2), and the distribution of parental drinking according to parental composition by adolescent binge drinking (Table 3).

Subsequently, the association between parental drinking (according to parental composition) and adolescent binge drinking was evaluated in generalized linear mixed models, addressing the clustering of adolescents in sample areas and schools [76]. Multivariable analysis was performed using logistic regression models to test the association. Three logistic regression models were established from unadjusted odds ratios and AORs together with $95 \%$ confidence interval $(\mathrm{Cl})$ for the factors. Model 1 included only FD, NF, MD, and NM. Model 2 included variables from Model 1, having been adjusted for all covariates. Model 3 included all variables from Model 1, the interaction between FD and MD, and the interaction between NF and NM combined, after having been adjusted for all covariates.

All data were coded and analyzed using IBM SPSS version 24 (IBM Corp., Armonk, NY, USA). A two-tailed $p$ value $<.05$ was considered statistically significant.

\section{Results}

\section{Descriptive statistics}

The completed surveys $(N=47,280$; response rate: $56 \%)$ were collected from students in 78 schools and 46,848 valid surveys were included for analysis. The demographic distribution of participants (male $=51.6 \%$; female $=48.4 \%$, given in Table 1 , shows 37,34 , and $29 \%$ are 1st, 2nd and 3rd-year students, respectively. The overall binge drinking prevalence was 2.3\%, (male= $2.7 \%$; female $=1.9 \%$ ) in the preceding month. The prevalence according to the frequency of paternal drinking was 33.2 and $32.9 \%$ for occasional and daily drinkers, respectively, but regarding maternal drinking frequency, it was 43.4 and $40.6 \%$ for occasional drinkers and "no drinking," respectively, which means, fathers tended to drink more frequently than mothers. Regarding parental composition, $83.8,13.4,1.7$, and $0.4 \%$ of the respondents live with both father and mother, only their mother, only their father, and neither parent, respectively. The rate of parental drinking according to parental composition showed that nearly half of the respondents $(42.9 \%)$ were 
Table 1 Distribution of respondents according to demographic variables

\begin{tabular}{|c|c|c|c|c|c|c|}
\hline & \multicolumn{6}{|c|}{ Sex } \\
\hline & \multicolumn{2}{|c|}{ Male } & \multicolumn{2}{|c|}{ Female } & \multicolumn{2}{|c|}{ Total } \\
\hline & $\mathrm{N}$ & $\%$ & $\mathrm{~N}$ & $\%$ & $\mathrm{~N}$ & $\%$ \\
\hline \multicolumn{7}{|l|}{ Grade } \\
\hline 1st-year & 9,035 & 37.4 & 8,337 & 36.9 & 17,372 & 37.2 \\
\hline 2nd-year & 8,268 & 34.2 & 7,606 & 33.7 & 15,874 & 34.0 \\
\hline 3rd-year & 6,845 & 28.3 & 6,631 & 29.4 & 13,476 & 28.8 \\
\hline \multicolumn{7}{|c|}{ Getting up at the same time every day } \\
\hline Yes & 20,929 & 86.7 & 19,681 & 87.3 & 40,610 & 87.0 \\
\hline No & 3,204 & 13.3 & 2,862 & 12.7 & 6,066 & 13.0 \\
\hline \multicolumn{7}{|c|}{ Going to the bed at the same time everyday } \\
\hline Yes & 14,241 & 59.1 & 12,619 & 56.0 & 26,860 & 57.6 \\
\hline No & 9,866 & 40.9 & 9,902 & 44.0 & 19,768 & 42.4 \\
\hline \multicolumn{7}{|l|}{ Breakfast eating } \\
\hline Yes & 22,011 & 91.2 & 21,278 & 94.3 & 43,289 & 92.7 \\
\hline No & 2,122 & 8.8 & 1,280 & 5.7 & 3,402 & 7.3 \\
\hline \multicolumn{7}{|l|}{ Enjoying school } \\
\hline Yes & 21,044 & 87.3 & 19,738 & 87.6 & 40,782 & 87.5 \\
\hline No & 3,057 & 12.7 & 2,789 & 12.4 & 5,846 & 12.5 \\
\hline Eating dinner with on & & & & & & \\
\hline Yes & 20,087 & 83.3 & 18,653 & 82.7 & 38,740 & 83.1 \\
\hline No & 4,014 & 16.7 & 3,892 & 17.3 & 7,906 & 16.9 \\
\hline Hours spent in the abs & & & & & & \\
\hline Less than 3 hours & 19,773 & 82.6 & 19,061 & 85.1 & 38,834 & 83.8 \\
\hline 3 hours or more & 4,168 & 17.4 & 3,348 & 14.9 & 7,516 & 16.2 \\
\hline Having close friends $t$ & & & & & & \\
\hline Yes & 22,939 & 95.4 & 21,900 & 97.3 & 44,839 & 96.3 \\
\hline No & 1,096 & 4.6 & 603 & 2.7 & 1,699 & 3.7 \\
\hline Having friends with $\mathrm{w}$ & & & & & & \\
\hline Yes & 21,529 & 89.8 & 20,992 & 93.6 & 42,521 & 91.7 \\
\hline No & 2,434 & 10.2 & 1,435 & 6.4 & 3,869 & 8.3 \\
\hline Drinking with peers & & & & & & \\
\hline Yes & 1,569 & 6.6 & 1,077 & 4.8 & 2,646 & 5.7 \\
\hline No & 22,263 & 93.4 & 21,303 & 95.2 & 43,566 & 94.3 \\
\hline Talking with one's par & & & & & & \\
\hline Yes & 14,661 & 61.2 & 17,411 & 77.6 & 32,072 & 69.2 \\
\hline No & 9,176 & 38.3 & 4,931 & 22.0 & 14,107 & 30.4 \\
\hline Thoughts on underage & & & & & & \\
\hline Not acceptable & 16,234 & 67.7 & 16,571 & 73.7 & 32,805 & 70.6 \\
\hline Acceptable & 7,762 & 32.3 & 5,914 & 26.3 & 13,676 & 29.4 \\
\hline Confidence in refusing & & & & & & \\
\hline Yes & 22,042 & 94.0 & 21,273 & 95.6 & 43,315 & 94.8 \\
\hline No & 1,408 & 6.0 & 981 & 4.4 & 2,389 & 5.2 \\
\hline Paternal drinking & & & & & & \\
\hline Every day & 7,644 & 31.8 & 7,650 & 34.0 & 15,294 & 32.9 \\
\hline Sometimes & 8,291 & 34.5 & 7,130 & 31.7 & 15,421 & 33.2 \\
\hline No & 5,058 & 21.1 & 4,242 & 18.9 & 9,300 & 20.0 \\
\hline Father is not at home & 3,020 & 12.6 & 3,456 & 15.4 & 6,476 & 13.9 \\
\hline Maternal drinking & & & & & & \\
\hline Every day & 3,120 & 13.0 & 3,333 & 14.8 & 6,453 & 13.9 \\
\hline Sometimes & 10,336 & 43.0 & 9,842 & 43.7 & 20,178 & 43.4 \\
\hline No & 10,029 & 41.7 & 8,886 & 39.5 & 18,915 & 40.6 \\
\hline Mother is not at home & 541 & 2.3 & 453 & 2.0 & 995 & 2.1 \\
\hline Parental composition & & & & & & \\
\hline Father and Mother & 20,529 & 85 & 18,657 & 82.6 & 39,186 & 83.8 \\
\hline Mother only & 2,900 & 12.0 & 3,347 & 14.8 & 6,247 & 13.4 \\
\hline Father only & 439 & 1.8 & 351 & 1.6 & 790 & 1.7 \\
\hline Neither & 102 & 0.4 & 98 & 0.4 & 200 & 0.4 \\
\hline Parental drinking ace & & & & & & \\
\hline $\mathrm{FN} / \mathrm{MN}$ & 3,428 & 14.3 & 2,762 & 12.3 & 6,190 & 13.3 \\
\hline $\mathrm{FN} / \mathrm{MD}$ & 1,542 & 6.4 & 1,387 & 6.2 & 2,929 & 6.3 \\
\hline $\mathrm{FN} / \mathrm{NM}$ & 86 & 0.4 & 93 & 0.4 & 179 & 0.4 \\
\hline $\mathrm{FD} / \mathrm{MN}$ & 5,354 & 22.3 & 4,800 & 21.4 & 10,154 & 21.9 \\
\hline $\mathrm{FD} / \mathrm{MD}$ & 10,205 & 42.6 & 9,708 & 43.2 & 19,913 & 42.9 \\
\hline $\mathrm{FD} / \mathrm{NM}$ & 353 & 1.5 & 258 & 1.1 & 611 & 1.3 \\
\hline $\mathrm{NF} / \mathrm{MN}$ & 1,218 & 5.1 & 1,298 & 5.8 & 2,516 & 5.4 \\
\hline $\mathrm{NF} / \mathrm{MD}$ & 1,682 & 7.0 & 2,049 & 9.1 & 3,731 & 8.0 \\
\hline $\mathrm{NF} / \mathrm{NM}$ & 102 & 0.4 & 98 & 0.4 & 200 & 0.4 \\
\hline Past month alcohol us & & & & & & \\
\hline No & 22,200 & 93.3 & 21,126 & 94.6 & 43,326 & 93.9 \\
\hline Yes & 1,590 & 6.7 & 1,215 & 5.4 & 2,805 & 6.1 \\
\hline Past month binge drin & & & & & & \\
\hline No & 23,141 & 97.3 & 21,909 & 98.1 & 45,050 & 97.7 \\
\hline Yes & 641 & 2.7 & 430 & 1.9 & 1,071 & 2.3 \\
\hline
\end{tabular}


Table 2 Distribution of respondents according to parental drinking and parental absence by adolescent binge drinking

\begin{tabular}{|c|c|c|c|c|c|}
\hline & \multicolumn{5}{|c|}{ Adolescent binge drinking } \\
\hline & \multicolumn{2}{|c|}{ No } & \multicolumn{2}{|c|}{ Yes } & \multirow{2}{*}{$\begin{array}{c}\text { Total } \\
\mathrm{N}\end{array}$} \\
\hline & $\mathrm{N}$ & $\%$ & $\mathrm{~N}$ & $\%$ & \\
\hline \multicolumn{6}{|c|}{ Father $(\mathrm{N}=46,079)$} \\
\hline $\mathrm{FN}$ & 9,089 & 98.4 & 151 & 1.6 & 9,240 \\
\hline FD & 29,720 & 97.7 & 707 & 2.3 & 30,427 \\
\hline $\mathrm{NF}$ & 6,196 & 96.6 & 216 & 3.4 & 6,412 \\
\hline \multicolumn{6}{|c|}{ Mother $(\mathrm{N}=46,141)$} \\
\hline $\mathrm{MN}$ & 18,474 & 98.4 & 293 & 1.6 & 18,767 \\
\hline MD & 25,669 & 97.3 & 721 & 2.7 & 26,390 \\
\hline NM & 924 & 93.9 & 60 & 6.1 & 984 \\
\hline
\end{tabular}

$\mathrm{FN}=$ Father does not drink, $\mathrm{FD}=$ Father drinks, $\mathrm{NF}=$ No father at home,

$\mathrm{MN}=$ Mother does not drink, $\mathrm{MD}=$ Mother drinks, $\mathrm{NM}=$ No mother at home

in the $\mathrm{FD} / \mathrm{MD}$ group, $21.9 \%$ in the $\mathrm{FD} / \mathrm{MN}$ group, and $13.3 \%$ in the FN/MN group.

Table 2 shows the distribution of respondents according to parental drinking and absence by adolescent binge drinking. Considering their fathers' status on alcohol use and absence, 3.4, 2.3, and 1.6\% of the respondents from the NF, FD, and FN groups, respectively, were highly experienced at binge drinking. Regarding their mothers' status on alcohol use and absence, 6.1, 2.7, and 1.6\% of the respondents in the NM, MD, and MN groups, respectively, had the most binge drinking experience.

Table 3 shows the distribution of respondents for parental drinking according to parental composition by adolescent binge drinking. Here, $15.6 \%$ of the respondents from the NF/NM group, $4.5 \%$ of the FD/NM group, $3.5 \%$ of the NF/MD group, $2.7 \%$ of the FN/MD group, and $2.6 \%$ of the FD/MD group, had extensive binge drinking experience.

\section{Associations between parental drinking according to parental composition and adolescent binge drinking}

Table 4 shows the results of logistic regression models reflecting the association between parental drinking according to parental composition and adolescent binge drinking. The results of Model 1 show that the NF, MD, and NM groups were significantly associated with

Table 3 Distribution of respondents for parental drinking according to parental composition by adolescent binge drinking

\begin{tabular}{|c|c|c|c|c|c|}
\hline & \multicolumn{5}{|c|}{ Adolescent binge drinking } \\
\hline & \multirow{2}{*}{\multicolumn{2}{|c|}{$\begin{array}{c}\text { No } \\
\mathrm{N}=44,958 \\
\end{array}$}} & \multirow{2}{*}{\multicolumn{2}{|c|}{$\begin{array}{c}\text { Yes } \\
\mathrm{N}=1,072 \\
\end{array}$}} & \multirow{3}{*}{$\begin{array}{c}\begin{array}{c}\text { Total } \\
\mathrm{N}=46,030 \\
\mathrm{~N}\end{array}\end{array}$} \\
\hline & & & & & \\
\hline & $\mathrm{N}$ & $\%$ & $\mathrm{~N}$ & $\%$ & \\
\hline $\mathrm{FN} / \mathrm{MN}$ & 6,076 & 98.8 & 71 & 1.2 & 6,147 \\
\hline $\mathrm{FN} / \mathrm{MD}$ & 2,836 & 97.3 & 78 & 2.7 & 2,914 \\
\hline $\mathrm{FN} / \mathrm{NM}$ & 176 & 98.9 & 2 & 1.1 & 178 \\
\hline $\mathrm{FD} / \mathrm{MN}$ & 9,904 & 98.4 & 165 & 1.6 & 10,069 \\
\hline $\mathrm{FD} / \mathrm{MD}$ & 19,205 & 97.4 & 514 & 2.6 & 19,719 \\
\hline $\mathrm{FD} / \mathrm{NM}$ & 576 & 95.5 & 27 & 4.5 & 603 \\
\hline NF/MN & 2,444 & 97.8 & 56 & 2.2 & 2,500 \\
\hline NF/MD & 3,573 & 96.5 & 128 & 3.5 & 3,701 \\
\hline $\mathrm{NF} / \mathrm{NM}$ & 168 & 84.4 & 31 & 15.6 & 199 \\
\hline
\end{tabular}

$\mathrm{FN}=$ Father does not drink, $\mathrm{FD}=$ Father drinks, $\mathrm{NF}=$ No father at home, 
Table 4 Logistic regression examining associations between parental drinking according to parental composition and adolescent binge drinking

\begin{tabular}{|c|c|c|c|c|c|c|}
\hline & \multicolumn{2}{|c|}{ Model 1: Unadjusted } & \multicolumn{2}{|c|}{ Model 2a : Adjusted for covariates } & \multicolumn{2}{|c|}{$\begin{array}{l}\text { Model } 3^{\mathrm{a}} \text { : Interactions between parental } \\
\text { drinking and parental absence }\end{array}$} \\
\hline & odds ratio $(95 \% \mathrm{Cl})$ & $p$ & odds ratio $(95 \% \mathrm{Cl})$ & $p$ & odds ratio $(95 \% \mathrm{Cl})$ & $p$ \\
\hline FD & $1.11(0.98-1.27)$ & .107 & $1.12(0.94-1.33)$ & .203 & $1.25(0.96-1.63)$ & .099 \\
\hline NF & $1.33(1.18-1.50)$ & $<.001^{*}$ & $1.16(0.95-1.41)$ & .142 & $1.18(0.84-1.65)$ & .355 \\
\hline MD & $1.60(1.47-1.75)$ & $<.001^{*}$ & $1.37(1.21-1.57)$ & $<.001^{*}$ & $1.50(1.06-2.12)$ & $.024^{*}$ \\
\hline NM & $2.17(1.71-2.76)$ & $<.001^{*}$ & $1.96(1.40-2.76)$ & $<.001^{*}$ & $1.52(0.91-2.52)$ & .107 \\
\hline $\mathrm{FD} \times \mathrm{MD}$ & & & & & $0.98(0.61-1.56)$ & .929 \\
\hline $\mathrm{NF} \times \mathrm{NM}$ & & & & & $4.35(2.10-9.02)$ & $<.001^{*}$ \\
\hline \multicolumn{7}{|c|}{$\mathrm{FD}=$ Father drinks, $\mathrm{NF}=$ No father at home, $\mathrm{MD}=$ Mother drinks, $\mathrm{NM}=$ =No mother at home, $\mathrm{CI}=$ Confidence interval $\quad P<.05 *$} \\
\hline \multicolumn{7}{|c|}{$\begin{array}{l}\text { a'Model } 2 \text { and Model } 3 \text { controls for gender, grade, getting up at the same time every day, going to the bed at the same time everyday, breakfast eating, } \\
\text { enjoying school, eating dinner with one's family, hours spent in the absence of adults, having close friends to hang out with, having friends with whom one } \\
\text { can consult, drinking with peers, talking with one's parent about one's problem, thoughts on underage drinking, and confidence in refusing a substance when } \\
\text { it is offered. }\end{array}$} \\
\hline
\end{tabular}

increased likelihoods of binge drinking by adolescents. The results of Model 2 show that only the mother's status of alcohol use (including MD and NM groups) was significantly associated with the outcome, after having been adjusted for 14 covariates. In Model 3, we examined the FD, NF, MD, and NM groups, as well as the interaction between FD and $\mathrm{MD}$, and the interaction between NF and NM groups, after adjusting for 14 covariates. In the final model, the MD group (AOR: 1.50, 95\% CI: $1.06-2.12)$ and the interaction between NF and NM groups (AOR: 4.35, 95\% CI: 2.10-9.02) showed significant associations with adolescent binge drinking. However, other associations between adolescent binge and parental drinking according to parental composition, including the FD group (AOR: 1.25, 95\% CI: 0.96-1.63), NF group (AOR: 1.18, 95\% CI: 0.84-1.65), NM group (AOR: 1.52 , 95\% CI: $0.91-2.52$ ), and FD/MD group (AOR: 0.98, 95\% CI: 0.61-1.56), were not confirmed.

\section{Discussion}

This is the first study to examine the relationship between parental drinking (according to parental composition) and binge drinking in a randomly selected nationally representative sample of high school students in Japan. In adjusted models (including 14 variables) the findings partly supported our hypothesis that adolescents whose mothers drink are more likely to engage in binge drinking. Also, adolescents who were not living with either parent may have been at greater risk of binge drinking.

\section{Effect of parental drinking}

This study revealed that mothers' drinking habits are significantly associated with binge drinking in adolescents, supporting our hypothesis that maternal drinking is associated with adolescent risky (including binge) drinking. Many studies reported that maternal drinking affect adolescent drinking behavior [47, 49, 50], potentially causing poor maternal parenting (related to support and supervision), promoting a favorable attitude to alcohol, and excessive and frequent adolescent drinking, in particular, when it is problematic [52-55].

Moreover, we mentioned that women are more likely to become problematic drinkers than men [51]. The number of Japanese men with drinking habits have decreased over the past decades, and the gap between their drinking habits and those of women is narrowing [77], possibly because of an increasing number of women with alcohol-related problems. The aforementioned evidence and possibilities may support the theory that mothers' drinking habits affected adolescents' risky drinking behavior in this study, just as maternal drinking affects adolescent alcohol misuse. Thus, our results imply that mothers' drinking may have a greater influence on adolescent alcohol misuse and risky (including binge) drinking, considering alcohol problems specific to women and their consequent reduced role at home.

In our study, fathers' drinking did not predict adolescent binge drinking. However, previous studies showed frequent and intense paternal drinking predicted excessive adolescent drinking [48], implying that drinking (which is similar to binge drinking) may affect children's binge drinking behavior. However, normal paternal drinking does not have much effect on children's risky drinking. In this regard, in Japanese families it is common for fathers to drink, thus implying that drinking is socially acceptable.

Another thought is that drinking habits are very common among fathers; the prevalence of drinking habits among men is overwhelmingly higher than among women [78]. However, the annual decrease in the proportion of male habitual drinkers in Japan is likely to be related to fewer overall problematic drinkers [77], which 
may be associated with our results. However, in this study, we did not examine the extent or frequency of parental drinking, which prevented us from screening and identifying them as normative or problematic drinkers. Hence, further study is needed.

Our study did not show that living in households where both parents drink may affect binge drinking in adolescents, thus failing to support the related hypothesis. Thus, the findings did not add to existing evidence that both parents (a) using alcohol, significantly predicted adolescent alcohol misuse (increasing the risk of drinking) [56-58], and (b) drinking heavily, predicted earlier onset and a stronger increase in adolescent drinking [46].

We applied the social learning theory to the effects of both parents drinking alcohol on their children's drinking behavior $[47,59,60]$. Both parents drinking, potentially increases the availability of alcohol at home, promoting a more acceptable attitude toward alcohol use, which potentially stimulates the onset of adolescent drinking in quantity and frequency.

Previous research suggested that there is a very strong association between adolescent drinking and excessive and frequent drinking by both parents [46], and higher levels of parental drinking is associated with increased alcohol availability at home [44]. Thus, the more frequently and heavily parents drink the higher the risk of adolescent binge drinking.

Apart from parental drinking, parenting itself is important since parental control (including monitoring), support, and warmth are crucial against risky drinking behavior [34]. Moderate control encourages children to make decisions and regulate their own behavior, whilst increased warmth and understanding support their autonomy [33]. Parental warmth also enhances bonding with children, potentially providing strong protection against deviant behavior [57]. Thus, even if both parents have drinking habits, well-balanced control, and support from them will enable sufficient socializing of their children to develop their autonomy to confront risky behaviors, including binge drinking.

\section{Effect of parental absence}

The current study showed that paternal absence and maternal absence were not significantly associated with adolescent binge drinking. This result did not support our hypothesis that paternal absence and maternal absence are associated with adolescent binge drinking. Our findings do not support the evidence that non-intact families are more likely to drink [33, 40], disrupted families are related to child binge drinking [31], children of single fathers were at higher risk of alcohol use [66], and that living with a single mother was associated with less heavy drinking than a single father [32]. Alcohol use and delinquent behaviors among adolescents were higher in single-father homes, than in single-mother homes [65]. However, the influence of single-parent households alone does not affect children's drinking. As mentioned earlier, both parents have important child nurturing roles, requiring parental control and support (including monitoring and warmth), which are crucial to preventing risky drinking behaviors [34]. Growing up in a supportive environment with moderate control, lowers the possibility of risky alcohol behaviors in children. There are several potential explanations why our results did not support existing research. The most likely reason is limited details about the absence of parents, since the definition of "having no parents" includes households where children are living alone owing to work. Divorce and bereavement have negative consequences on children. However, that situation differs from one where parents are separated from their children owing to work. Furthermore, we also did not examine family structures in our study, which may have impacted the result. Other family members or relatives may play the role of the absent parent providing family support and control [33, 45]. A single-parent household survey in Japan, showed that nearly half of single-parent households have cohabitants [79]. Thus, even in households without one parent, other family members could play an important parenting role. Furthermore, divorce rates and family composition differ between cultures. Therefore, it is desirable to discuss parental and extended or immediate family composition to shed light on the reasons for having no parents. Despite these limitations we concluded that the absence of one parent did not affect children's binge drinking.

Our results revealed that adolescents without either parent are associated with binge drinking, supporting previous findings that children who do not live with both their biological parents consume alcohol more frequently and heavily $[32,33,69]$. In this regard, research indicated that "custodial grandchildren typically receive care from grandparents because of predicaments among their parents, such as substance abuse, child abuse and neglect, teenage pregnancy, death, illness, divorce, incarceration, and HIV/ AIDS." [80] Still, we infer that children not living with either parent, were living in a difficult environment compared to at least a single-parent household. Not living with either parent can affect the socialization and development of an adolescent [33] and living in a fragmented family increases the risk of frequent drinking and drunkenness among adolescents [67]. Binge drinking does not appear in families where protective parental (including monitoring, warmth, and parent-child communication) factors are present [34]. Thus, our finding suggested that children who do not live with either parent may be a high-risk group for binge drinking. 


\section{Limitations}

There are several limitations to our research. First, owing to its cross-sectional design, we were unable to examine the temporal relationship between parental and child binge drinking; longitudinal design studies are recommended. Owing to secondary data analysis, we were unable to consider several potentially important factors including genetic predispositions, adverse childhood experiences, social influences, and parental mental health. In addition, data regarding parental drinking were collected from the children and depended on their perceptions; therefore, the representativeness thereof may not be accurate. No survey questions regarding the amount and frequency of drinking by parents were included, so we were unable to distinguish whether parents were problematic drinkers or not. In future research, data should be collected from both the parents and children, including items querying the amount and frequency of drinking. Furthermore, our questionnaire did not include items regarding the reasons for single- or neither parent household, therefore the definitions of "single" and "neither" parent were ambiguous. The cause of family deficiency varies depending on country and culture, and hence, which parent group most likely influences Japanese children's risk behavior needs to be determined. Finally, we did not examine whether parental drinking influenced adolescents according to sex and further longitudinal studies assessing the deferential effects are needed, as past results have been inconsistent [56]. Further research should investigate adolescent binge drinking according to sex differences, clarifying the relationship between drinking in parents and their children. Despite these limitations, this was the first nationwide study to examine the relationship between parents' drinking (according to parental composition) and adolescent binge drinking. Our findings, that maternal drinking behavior and non-parental families influence binge drinking behavior in Japanese high school students, provide useful information on the parental factors that contribute to binge drinking in these students. We recommend an enhanced prevention program, engaging parents and non-parental family, educating them about the effects of alcohol use on children and proactive family practice. Finally, since this survey was a secondary analysis of the Nationwide Survey, we could not examine all possible factors that influence binge drinking, nevertheless we were able to estimate possible associations among specific variables. We hope that our findings will contribute toward future binge drinking research.

\section{Conclusions}

Using a nationally representative sample of Japanese high school students, the findings of the present research suggest that adolescents whose mothers drink or do not live with them at home may be more at risk of binge drinking. Our findings add substantial evidence to that of previous studies regarding parental drinking and adolescent alcohol misuse. Focusing on parental engagement (including non-parental family members) in future programs and interventions is important in preventing adolescent binge drinking. We hope our findings will prove useful to future binge drinking research. Future analyses should explore whether parental drinking (according to parental composition), considering the amount and frequency of drinking, affects adolescent binge drinking by gender differences.

\section{Abbreviations \\ AOR: Adjusted odds ratio; Cl: Confidence interval; FN: Father does not drink; FD: Father drinks; NF: No father at home; MN: Mother does not drink; MD: Mother drinks; NM: No mother at home}

\section{Acknowledgements}

All authors wish to thank Dr. Katsuno and Dr. Miyoshi, who initiated the Nationwide High School Survey, for their assistance and engagement at the beginning of the survey. We would like to thank Takahiro Matsumura, Wakara Corp for giving necessary guidance for analysis. We also thank Analisa Avila, ELS, of Edanz Group (www.edanzediting.com/ac) and Taylor \& Francis Editing Services (www.tandfeditingservices.com) for editing a draft of this manuscript.

\section{Authors' contributions}

TS and TM conceived the study and initiated its design. TS, SI, KK, KW, and TM developed the questionnaire. TS and SI coordinated and carried out the study, collected data, and performed the statistical analyses. SI and TS

drafted the manuscript. All authors have read and approved the manuscript.

\section{Funding}

This study was funded by the Ministry of Health, Labor and Welfare of Japan, Research Project on Addiction. The funding agency had no role in the study design, data collection, data analysis, manuscript writing, or publication.

\section{Availability of data and materials}

The raw data and datasets used and/or analyzed for the current study are not publicly available but are available from the corresponding author on reasonable request. A report on the Nationwide High School Survey on Drug Use and Lifestyle 2018 is also available from the Department of Drug Dependence Research, National Institute of Mental Health, National Center of Neurology and Psychiatry: https://www.ncnp.go.jp/nimh/yakubutsu/index_ eng.html.

\section{Ethics approval and consent to participate}

The current study was approved by the Committee on the Ethical Guidelines for Medical and Health Research Involving Human Subjects of the National Center of Neurology and Psychiatry (Approval No: A2018-055). All study participants were fully briefed about the nature of the study, the voluntary nature of its completion, and their rights as participants. Participants were also informed that completion of the questionnaire constituted consent to participate; thus, if a participant returned a completed questionnaire to the person in charge of substance abuse prevention at each school, that action signaled consent. This process of obtaining consent was approved by the ethics committee. 


\section{Competing interests}

The authors declare that they have no competing interests.

\section{Author details}

'Department of Drug Dependence Research, National Institute of Mental Health, National Center of Neurology and Psychiatry, Tokyo, Japan. ${ }^{2}$ Social Pharmacy Lab., Faculty of Pharmaceutical Sciences, Tokyo University of Pharmacy and Life Sciences, Tokyo, Japan. ${ }^{3}$ Department of Addiction Treatment Research, Saitama Prefectural Psychiatric Hospital, Saitama, Japan.

Received: 17 February 2020 Accepted: 25 November 2020 Published online: 07 December 2020

\section{References}

1. Shimane T, Inoura S, Kitagaki K, Wada K, Matsumoto T. 2018 Nationwide high school student survey on drug use and lifestyle [Report]. National Center of Neurology and Psychiatry; 2019. https://www.ncnp.go.jp/nimh/ yakubutsu/report/index.html. Accessed 3 Dec 2020.

2. Monitoring the Future 2019 Survey results: overall findings: National Institute of health, National Institute on Drug Abuse; 2019. https://www. drugabuse.gov/drug-topics/trends-statistics/infographics/monitoringfuture-2019-survey-results-overall-findings. Accessed 3 Dec 2020.

3. ESPAD Report 2015: The European School Survey Project on Alcohol and Other Drugs; 2015. http://www.espad.org/content/table-20a-frequencyhaving-had-five-or-more-drinks-one-occasion-during-last-30-days-2015. Accessed 3 Dec 2020

4. Hingson R, White A. New research findings since the 2007 surgeon General's call to action to prevent and reduce underage drinking: a review. J Stud Alcohol Drugs. 2014;75(1):158-69. https://doi.org/10.15288/jsad.2014. 75.158.

5. Kuntsche E, Kuntsche S, Thrul J, Gmel G. Binge drinking: health impact, prevalence, correlates and interventions. Psychol Health. 2017;32(8):9761017. https://doi.org/10.1080/08870446.2017.1325889.

6. Stickley A, Koyanagi A, Koposov R, Razvodovsky Y, Ruchkin V. Adolescent binge drinking and risky health behaviours: findings from northern Russia. Drug Alcohol Depend. 2013;133(3):838-44. https://doi.org/10.1016/j. drugalcdep.2013.08.028.

7. Waterman EA, Lee KDM, Edwards KM. Longitudinal associations of binge drinking with interpersonal violence among adolescents. J Youth Adolesc 2019:48(7):1342-52. https://doi.org/10.1007/s10964-019-01035-w.

8. Chung T, Creswell KG, Bachrach R, Clark DB, Martin CS. Adolescent binge drinking. Alcohol Res. 2018;39(1):5-15.

9. Risks of drinking that high school students should know: Drinking prevention education support committee at school, Japan society of school health; 2016. https://www.gakkohoken.jp/book/ebook/ebook_H290030/H2 90030.pdf. Accessed 3 Dec 2020.

10. Shimane T, Wada K, Mishima K, Fujiwara M. Association between risky drinking behaviors and risk groups of substance abuse: a study in Japanese college freshmen. Nihon Arukoru Yakubutsu lgakkai Zasshi. 2009;44(6):649-58.

11. Yoshimoto H, Takayashiki A, Goto R, Saito G, Kawaida K, Hieda R, et al. Association between excessive alcohol use and alcohol-related injuries in college students: a multi-center cross-sectional study in Japan. Tohoku J Exp Med. 2017;242(2):157-63. https://doi.org/10.1620/tjem.242.157.

12. Borrell-Carrio F, Suchman AL, Epstein RM. The biopsychosocial model 25 years later: principles, practice, and scientific inquiry. Ann Fam Med. 2004; 2(6):576-82. https://doi.org/10.1370/afm.245

13. Heilig M, Goldman D, Berrettini W, O'Brien CP. Pharmacogenetic approaches to the treatment of alcohol addiction. Nat Rev Neurosci. 2011;12(11):670-84. https://doi.org/10.1038/nrn3110.

14. Kreek M, Nielsen D, Butelman E, LaForge K. Genetic influences on impulsivity, risk taking, stress responsivity and vulnerability to drug abuse and addiction. Nat Neurosci. 2005;8:1450-7. https://doi.org/10.1038/nn1583.

15. Chen C-C, Lu R-B, Chen Y-C, Wang M-F, Chang Y-C, Li T-K, et al. Interaction between the functional polymorphisms of the alcohol-metabolism genes in protection against alcoholism. Am J Hum Genet. 1999;65(3):795-807. https://doi.org/10.1086/302540.

16. Spanagel $R$, Noori $H$, Heilig M. Stress and alcohol interactions: animal studies and clinical significance. Trends Neurosci. 2014;37(4):219-27. https:// doi.org/10.1016/j.tins.2014.02.006
17. Koob GF, Buck CL, Cohen A, Edwards S, Park PE, Schlosburg JE, et al. Addiction as a stress surfeit disorder. Neuropharmacology. 2014;76(Pt B): 370-82. https://doi.org/10.1016/j.neuropharm.2013.05.024.

18. lacono WG, Malone SM, McGue M. Behavioral disinhibition and the development of early-onset addiction: common and specific influences. Annu Rev Clin Psychol. 2008;4:325-48. https://doi.org/10.1146/annurev. clinpsy.4.022007.141157.

19. Kreek MJ, Nielsen DA, LaForge KS. Genes associated with addiction: alcoholism, opiate, and cocaine addiction. NeuroMolecular Med. 2004;5(1): 85-108. https://doi.org/10.1385/nmm:5:1:085.

20. Foll BL, Gallo A, Strat YL, Lu L, Gorwood P. Genetics of dopamine receptors and drug addiction: a comprehensive review. Behav Pharmacol. 2009;20(1): 1-17. https://doi.org/10.1097/FBP.0b013e3283242f05.

21. McClintick JN, McBride WJ, Bell RL, Ding ZM, Liu Y, Xuei X, et al. Gene expression changes in the ventral hippocampus and medial prefrontal cortex of adolescent alcohol-preferring $(P)$ rats following binge-like alcohol drinking. Alcohol. 2018;68:37-47. https://doi.org/10.1016/j.alcohol.2017.09.002.

22. Seneviratne C, Franklin J, Beckett K, Ma JZ, Ait-Daoud N, Payne TJ, et al. Association, interaction, and replication analysis of genes encoding serotonin transporter and 5-HT3 receptor subunits a and B in alcohol dependence. Hum Genet. 2013;132(10):1165-76. https://doi.org/10.1007/ s00439-013-1319-y.

23. Hawkins JD, Catalano RF, Miller JY. Risk and protective factors for alcohol and other drug problems in adolescence and early adulthood: implications for substance abuse prevention. Psychol Bull. 1992;112(1):64-105. https:// doi.org/10.1037/0033-2909.112.1.64

24. Patton $\mathrm{JH}$, Stanford MS, Barratt ES. Factor structure of the Barratt impulsiveness scale. J Clin Psychol. 1995;51(6):768-74. https://doi.org/10. 1002/1097-4679(199511)51:6<768::AID-JCLP2270510607>3.0.CO;2-1.

25. Stautz K, Cooper A. Impulsivity-related personality traits and adolescent alcohol use: a meta-analytic review. Clin Psychol Rev. 2013;33(4):574-92. https://doi.org/10.1016/j.cpr.2013.03.003.

26. Shulman EP, Harden KP, Chein JM, Steinberg L. Sex differences in the developmental trajectories of impulse control and sensation-seeking from early adolescence to early adulthood. J Youth Adolescence. 2015;44(1):1-17. https://doi.org/10.1007/s10964-014-0116-9.

27. Miranda R Jr, Monti PM, Ray L, Treloar HR, Reynolds EK, Ramirez J, et al. Characterizing subjective responses to alcohol among adolescent problem drinkers. J Abnorm Psychol. 2014;123(1):117-29. https://doi.org/10.1037/ a0035328.

28. Behar D, Berg CJ, Rapoport JL, Nelson W, Linnoila M, Cohen M, et al. Behavioral and physiological effects of ethanol in high-risk and control children: a pilot study. Alcohol Clin Exp Res. 1983;7(4):404-10. https://doi. org/10.1111/j.1530-0277.1983.tb05495.x.

29. Spear L. Alcohol consumption in adolescence: a translational perspective. Curr Addict Rep. 2016;3:50-61. https://doi.org/10.1007/s40429-016-0088-9.

30. Brown SA, McGue M, Maggs J, Schulenberg J, Hingson R, Swartzwelder S, et al. A developmental perspective on alcohol and youths 16 to 20 years of age. Pediatrics. 2008;121(Suppl 4):S290-310. https://doi.org/10.1542/peds. 2007-2243D

31. Tucker JS, Orlando M, Ellickson PL. Patterns and correlates of binge drinking trajectories from early adolescence to young adulthood. Health Psychol. 2003:22(1):79-87. https://doi.org/10.1037//0278-6133.22.1.79.

32. Bjarnason T, Andersson B, Choquet M, Elekes Z, Morgan M, Rapinett G. Alcohol culture, family structure and adolescent alcohol use: multilevel modeling of frequency of heavy drinking among 15-16 year old students in 11 European countries. J Stud Alcohol. 2003;64(2):200-8. https://doi.org/10. 15288/jsa.2003.64.200

33. Foxcroft DR, Lowe G. Adolescent drinking behaviour and family socialization factors: a meta-analysis. J Adolesc. 1991;14(3):255-73. https://doi.org/10. 1016/0140-1971(91)90020-R.

34. Donaldson CD, Handren LM, Crano WD. The enduring impact of parents' monitoring, warmth, expectancies, and alcohol use on their children's future binge drinking and arrests: a longitudinal analysis. Prev Sci. 2016;17(5):60614. https://doi.org/10.1007/s11121-016-0656-1.

35. Mair C, Lipperman-Kreda S, Gruenewald PJ, Bersamin M, Grube JW. Adolescent drinking risks associated with specific drinking contexts. Alcohol Clin Exp Res. 2015;39(9):1705-11. https://doi.org/10.1111/acer.12806.

36. Hahm HC, Kolaczyk E, Jang J, Swenson T, Bhindarwala AM. Binge drinking trajectories from adolescence to young adulthood: the effects of peer social 
network. Subst Use Misuse. 2012;47(6):745-56. https://doi.org/10.3109/ 10826084.2012.666313.

37. Leung RK, Toumbourou JW, Hemphill SA. The effect of peer influence and selection processes on adolescent alcohol use: a systematic review of longitudinal studies. Health Psychol Rev. 2014;8(4):426-57. https://doi.org/10. 1080/17437199.2011.587961.

38. Lo CC, Weber J, Cheng TC. A spatial analysis of student binge drinking, alcohol-outlet density, and social disadvantages. Am J Addict. 2013;22(4): 391-401. https://doi.org/10.1111/j.1521-0391.2013.12022.x.

39. Rossow I, Felix L, Keating P, McCambridge J. Parental drinking and adverse outcomes in children: a scoping review of cohort studies. Drug Alcohol Rev. 2016;35(4):397-405. https://doi.org/10.1111/dar.12319.

40. Donovan JE. Adolescent alcohol initiation: A review of psychosocial risk factors. J Adolescent Health. 2004;35(6):529.e7-.e18. https://doi.org/10.1016/j. jadohealth.2004.02.003

41. Yap MBH, Cheong TWK, Zaravinos-Tsakos F, Lubman DI, Jorm AF. Modifiable parenting factors associated with adolescent alcohol misuse: a systematic review and meta-analysis of longitudinal studies. Addiction. 2017;112(7): 1142-62. https://doi.org/10.1111/add.13785.

42. Rossow I, Keating P, Felix L, McCambridge J. Does parental drinking influence children's drinking? A systematic review of prospective cohort studies. Addiction. 2016;111(2):204-17. https://doi.org/10.1111/add.13097.

43. Yamazaki S. Children of alcoholics screening test and influence of parent's drinking on their children. J Pub Health. 1996;43(12):1045-54.

44. Van Zundert RM, Van Der Vorst $H$, Vermulst AA, Engels RC. Pathways to alcohol use among Dutch students in regular education and education for adolescents with behavioral problems: the role of parental alcohol use, general parenting practices, and alcohol-specific parenting practices. J Fam Psychol. 2006;20(3):456-67. https://doi.org/10.1037/0893-3200.20.3.456.

45. Tildesley EA, Andrews JA. The development of children's intentions to use alcohol: direct and indirect effects of parent alcohol use and parenting behaviors. Psychol Addict Behav. 2008;22(3):326-39. https://doi.org/10.1037/ 0893-164x.22.3.326

46. Vermeulen-Smit E, Koning IM, Verdurmen JEE, Van der Vorst $H$, Engels RCME, Vollebergh WAM. The influence of paternal and maternal drinking patterns within two-partner families on the initiation and development of adolescent drinking. Addict Behav. 2012;37(11):1248-56. https://doi.org/10. 1016/j.addbeh.2012.06.005.

47. Alati R, Baker P, Betts KS, Connor JP, Little K, Sanson A, et al. The role of parental alcohol use, parental discipline and antisocial behaviour on adolescent drinking trajectories. Drug Alcohol Depend. 2014;134:178-84. https://doi.org/10.1016/j.drugalcdep.2013.09.030.

48. Mares SH, van der Vorst H, Engels RC, Lichtwarck-Aschoff A. Parental alcohol use, alcohol-related problems, and alcohol-specific attitudes, alcohol-specific communication, and adolescent excessive alcohol use and alcohol-related problems: an indirect path model. Addict Behav. 2011;36(3):209-16. https:// doi.org/10.1016/j.addbeh.2010.10.013.

49. Cortes RC, Fleming CB, Mason WA, Catalano RF. Risk factors linking maternal depressed mood to growth in adolescent substance use. J Emot Behav Disord. 2009;17(1):49-64. https://doi.org/10.1177/1063426608321690.

50. Casswell S, Pledger M, Pratap S. Trajectories of drinking from 18 to 26 years: identification and prediction. Addiction. 2002;97(11):1427-37. https://doi org/10.1046/j.1360-0443.2002.00220.x.

51. Maesato H, Matsushita S, Higuchi S. Women's alcohol dependence. J Japan Med Assoc. 2011;140(9):1890-4

52. Finan LJ, Schulz J, Gordon MS, Ohannessian CM. Parental problem drinking and adolescent externalizing behaviors: the mediating role of family functioning. J Adolesc. 2015;43:100-10. https://doi.org/10.1016/j. adolescence.2015.05.001.

53. Hemovich V, Crano WD. Family structure and adolescent drug use: an exploration of single-parent families. Substance Use Misuse. 2009;44(14): 2099-113. https://doi.org/10.3109/10826080902858375.

54. Ennett ST, Jackson C, Bowling JM, Dickinson DM. Parental socialization and children's susceptibility to alcohol use initiation. J Stud Alcohol Drugs. 2013; 74(5):694-702. https://doi.org/10.15288/jsad.2013.74.694.

55. Osaki Y, Suzuki K, Wada K, Hitsumoto S. Association of parental factors with student smoking and alcohol use in Japan. Jpn J Alcohol Dependence. 2011;46(2):270-8.

56. Homel J, Warren D. The relationship between parent drinking and adolescent drinking: differences for mothers and fathers and boys and girls.
Substance Use Misuse. 2019;54(4):661-9. https://doi.org/10.1080/10826084. 2018.1531429.

57. Hung C-C, Yen L-L, Wu W-C. Association of parents' alcohol use and family interaction with the initiation of alcohol use by sixth graders: a preliminary study in Taiwan. BMC Public Health. 2009;9(1):172. https://doi.org/10.1186/ 1471-2458-9-172.

58. Green G, Macintyre S, West P, Ecob R. Like parent like child? Associations between drinking and smoking behaviour of parents and their children. 1991:745-58. https://doi.org/10.1111/j.1360-0443.1991.tb03100.x.

59. Bandura - Social learning Theory: Simply Psychology; 2016. https://www. simplypsychology.org/simplypsychology.org-bandura.pdf. Accessed 3 Dec 2020.

60. Hearst MO, Fulkerson JA, Maldonado-Molina MM, Perry CL, Komro KA. Who needs liquor stores when parents will do? The importance of social sources of alcohol among young urban teens. Prev Med. 2007;44(6):471-6. https:// doi.org/10.1016/j.ypmed.2007.02.018.

61. Osaki Y, Tanihata T, Ohida T, Kanda H, Kaneita Y, Minowa M, et al. Decrease in the prevalence of smoking among Japanese adolescents and its possible causes: periodic nationwide cross-sectional surveys. Environ Health Prev Med. 2008;13(4):219-26. https://doi.org/10.1007/s12199-008-0033-1.

62. Staff J, Maggs JL. Parents allowing drinking is associated with adolescents' heavy alcohol use. Alcohol Clin Exp Res. 2020;44(1):188-95. https://doi.org/ 10.1111/acer.14224.

63. Bryant L, MacKintosh AM, Bauld L. An exploration of the impact of nondependent parental drinking on children. Alcohol Alcohol. 2019;55(1):121-7. https://doi.org/10.1093/alcalc/agz086.

64. Kask K, Markina A, Podana Z. The effect of family factors on intense alcohol use among european adolescents: a multilevel analysis. Psychiatry J. 2013; 2013:12. https://doi.org/10.1155/2013/250215.

65. Cookston JT. Parental supervision and family structure: effects on adolescent problem behaviors. J Divorce Remarriage. 1999;32(1-2):107-22. https://doi. org/10.1300/J087v32n01_07.

66. Jablonska B, Lindberg L. Risk behaviours, victimisation and mental distress among adolescents in different family structures. Soc Psychiatry Psychiatr Epidemiol. 2007;42(8):656-63. https://doi.org/10.1007/s00127-007-0210-3.

67. Tomcikova Z, Veselska ZD, Geckova AM, van Dijk JP, Reijneveld SA. Adolescents' drinking and drunkenness more likely in one-parent families and due to poor communication with mother. Cent Eur J Public Health. 2015;23(1):54-8. https://doi.org/10.21101/cejph.a3951.

68. Shek DT, Xie Q, Lin L. The impact of family intactness on family functioning, parental control, and parent-child relational qualities in a chinese context. Front Pediatr. 2014;2:149. https://doi.org/10.3389/fped.2014.00149.

69. Miller P. Family structure, personality, drinking, smoking and illicit drug use: a study of UK teenagers. Drug Alcohol Depend. 1997;45(1-2):121-9. https:// doi.org/10.1016/s0376-8716(97)01345-8.

70. H28 zenkoku hitori-oya-setai-tou tyousa: Status of caregiver households: Ministry of Health, Labour and Welfare; 2016. https://www.mhlw.go.jp/file/ 06-Seisakujouhou-11920000-Kodomokateikyoku/0000188180.pdf. Accessed 3 Dec 2020.

71. Alcohol use fact \& resources: Substance Abuse and Mental Health Services Administration (SAMHSA). https://www.samhsa.gov/sites/default/files/ alcohol_use_facts_and_resources_fact_sheet_2018_data.pdf. Accessed 3 Dec 2020

72. Torvik FA, Rognmo K, Ask H, Røysamb E, Tambs K. Parental alcohol use and adolescent school adjustment in the general population: results from the HUNT study. BMC Public Health. 2011;11(1):706. https://doi.org/10.1186/ 1471-2458-11-706.

73. Soloski K, Monk J, Durtschi J. Trajectories of early binge drinking: a function of family cohesion and peer use. J Marital Fam Ther. 2015;42. https://doi. org/10.1111/jmft.12111.

74. Xiao Z, Li X, Stanton B. Perceptions of parent-adolescent communication within families: it is a matter of perspective. Psychol Health Med. 2011;16(1): 53-65. https://doi.org/10.1080/13548506.2010.521563.

75. Andrews J, Tildesley E, Hops H, Duncan S, Severson H. Elementary school age children's future intentions and use of substances. J Clin Child Adolescent Psychol. 2004;32:556-67. https://doi.org/10.1207/ S15374424JCCP3204_8.

76. Brumback BA, Dailey AB, Brumback LC, Livingston MD, He Z. Adjusting for confounding by cluster using generalized linear mixed models. Stat Probability Lett. 2010;80(21):1650-4. https://doi.org/10.1016/j.spl.2010.07.006. 
77. H30 zenkoku kokumin-kenkou-eiyou-tyousa: Ministry of Health, Labor and Welfare; 2018. https://www.mhlw.go.jp/stf/seisakunitsuite/bunya/kenkou_ iryou/kenkou/eiyou/h30-houkoku_00001.html. Accessed 3 Dec 2020.

78. Nolen-Hoeksema S. Gender differences in risk factors and consequences for alcohol use and problems. Clin Psychol Rev. 2004;24(8):981-1010. https://doi.org/10.1016/j.cpr.2004.08.003.

79. H28 zenkoku hitori-oya-setai-tou tyousa: Status of single parent households: Ministry of Health, Labour and Welfare; 2016. https://www.mhlw.go.jp/file/ 06-Seisakujouhou-11920000-Kodomokateikyoku/0000188154.pdf. Accessed 3 Dec 2020.

80. Pinson-Millburn NM, Fabian ES, Schlossberg NK, Pyle M. Grandparents raising grandchildren. J Counseling Dev. 1996;74(6):548-54. https://doi.org/ 10.1002/j.1556-6676.1996.tb02291.x.

\section{Publisher's Note}

Springer Nature remains neutral with regard to jurisdictional claims in published maps and institutional affiliations.

Ready to submit your research? Choose BMC and benefit from:

- fast, convenient online submission

- thorough peer review by experienced researchers in your field

- rapid publication on acceptance

- support for research data, including large and complex data types

- gold Open Access which fosters wider collaboration and increased citations

- maximum visibility for your research: over $100 \mathrm{M}$ website views per year

At BMC, research is always in progress.

Learn more biomedcentral.com/submissions 